\title{
Detection of pollution transport events southeast of Mexico City using ground-based visible spectroscopy measurements of nitrogen dioxide
}

\author{
M. L. Melamed ${ }^{1}$, R. Basaldud ${ }^{1}$, R. Steinbrecher ${ }^{2}$, S. Emeis ${ }^{2}$, L. G. Ruíz-Suárez ${ }^{1}$, and M. Grutter ${ }^{1}$ \\ ${ }^{1}$ Centro de Ciencias de la Atmósfera, Univ. Nacional Autónoma de México, México D.F., México \\ ${ }^{2}$ Institute for Meteorology and Climate Research, Atmospheric Environmental Research (IMK-IFU), \\ Forschungszentrum Karlsruhe GmbH, Garmisch-Partenkirchen, Germany
}

Received: 19 December 2008 - Published in Atmos. Chem. Phys. Discuss.: 24 February 2009

Revised: 9 June 2009 - Accepted: 7 July 2009 - Published: 22 July 2009

\begin{abstract}
This work presents ground based differential optical absorption spectroscopy (DOAS) measurements of nitrogen dioxide $\left(\mathrm{NO}_{2}\right)$ during the MILAGRO field campaign in March 2006 at the Tenango del Aire research site located to the southeast of Mexico City. The DOAS $\mathrm{NO}_{2}$ column density measurements are used in conjunction with ceilometer, meteorological and surface nitric oxide (NO), nitrogen oxides $\left(\mathrm{NO}_{\mathrm{x}}\right)$ and total reactive nitrogen $\left(\mathrm{NO}_{\mathrm{y}}\right)$ measurements to analyze pollution transport events to the southeast of Mexico City during the MILARGO field campaign. The study divides the data set into three case study pollution transport events that occurred at the Tenango del Aire research site. The unique data set is then used to provide an in depth analysis of example days of each of the pollution transport events. An in depth analysis of 13 March 2006, a Case One day, shows the transport of several air pollution plumes during the morning through the Tenango del Aire research site when southerly winds are present and demonstrates how DOAS tropospheric $\mathrm{NO}_{2}$ vertical column densities (VCD), surface $\mathrm{NO}_{2}$ mixing ratios and ceilometer data are used to determine the vertical homogeneity of the pollution layer. The analysis of 18 March 2006, a Case Two day, shows that when northerly winds are present for the entire day, the air at the Tenango del Aire research site is relatively clean and no major pollution plumes are detected. Case 3 days are characterized by relatively clean air throughout the morning with large DOAS $\mathrm{NO}_{2}$ enhancements detected in the afternoon.
\end{abstract}

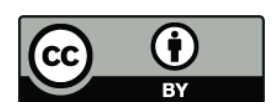

Correspondence to: M. L. Melamed (megan.melamed@gmail.com)
The analysis of 28 March 2006 show the DOAS $\mathrm{NO}_{2}$ enhancements are likely due to lightning activity and demonstrate how suitable ground-based DOAS measruements are for monitoring anthropogenic and natural pollution sources that reside above the mixing layer.

\section{Introduction}

Megacities (cities with a population greater than 10 million) play a critical role in local, regional and global air pollution. One megacity of primary interest is Mexico City, the world's second largest city with an estimated population of 22 million within an area of $1500 \mathrm{~km}^{2}$. Mexico City is located in the sub-tropics at $19^{\circ} \mathrm{N}$ and $99^{\circ} \mathrm{W}$ at $2240 \mathrm{~m}$ a.s.l. in a flat basin surrounded by mountains on three sides. The primary sources of pollution in Mexico City are transportation, industrial processes and domestic related activities. The high-density population, the unique geographical setting and multiple emission sources lead to high pollution episodes on a regular basis in Mexico City. These episodes have serious immediate and longer-term impacts on human health and the environment.

Recent research has begun to unravel the complexity of the air pollution problem in Mexico City and its effects not only on a local but on a regional and global scales as well. Since 1986, an automated network for atmospheric monitoring in Mexico City (Red Automatica de Monitoreo Ambiental or RAMA) has been measuring surface mixing ratios of ozone $\left(\mathrm{O}_{3}\right)$, nitrogen oxides $\left(\mathrm{NO}_{\mathrm{x}}\right)$, carbon monoxide $(\mathrm{CO})$, sulfur dioxide $\left(\mathrm{SO}_{2}\right)$ and particulate matter

Published by Copernicus Publications on behalf of the European Geosciences Union. 


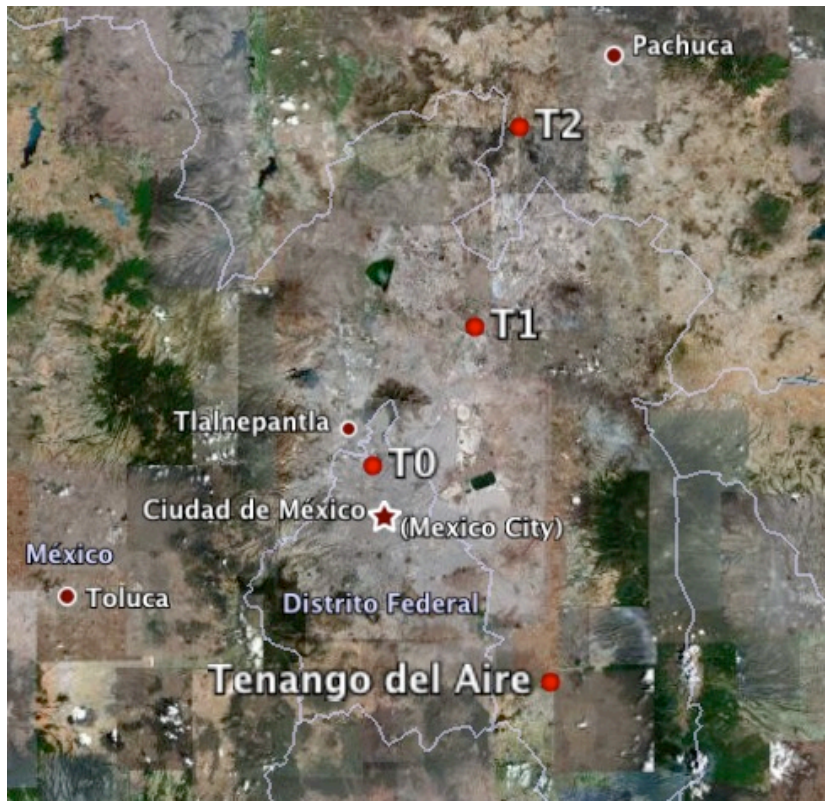

Fig. 1. Map of the Mexico City metropolitan area indicating the T0, $\mathrm{T} 1$ and T2 supersites as well as the Tenango del Aire research site to the southeast of the city center.

( $\left.\mathrm{PM}_{10}\right)$, (http://www.sma.df.gob.mx/simat). Meteorological data has been available since 1948 from the National Meteorology Service, (http://smn2.cna.gob.mx). In addition to these continuous measurements, several large-scale, intensive field campaigns have augmented the data-base of air pollution and meteorological profiles. These include the Mexico City Air Quality Initiative (MARI 1990-1993), the Investigación sobre Materia Particulada y Deterioro AtmosfericoAerosol and Visibility Research (IMADA-AVER 1997) and the Mexico City Metropolitan Area (MCMA 2003) experiment (Molina and Molina, 2002). In response to previous studies the Megacity Initiative: Local and Global Research Observations (MILAGRO 2006) campaign took place during March of 2006. The goal of MILAGRO 2006 was to conduct measurements of gas phase and aerosol air pollutants in the Mexico City metropolitan area in order to study the transport and transformation of the measured air pollutants on local, regional and global scales (http://www.eol.ucar.edu/projects/ milagro/). The MILAGRO 2006 campaign had three primary surface research sites (T0, T1 and T2) to study the transport of pollution from the city center to the northeast. To date, many articles have been published from these three surface research sites, (Doran et al., 2007; DeCarlo et al., 2008; Moffet et al., 2008; Querol et al., 2008; Stone et al., 2008; Thornhill et al., 2008; Hennigan et al., 2008, and references therein).

Here, we present an analysis of pollution transport events to the southeast of Mexico City through the Tenango del Aire research site using a unique data set of surface ni-

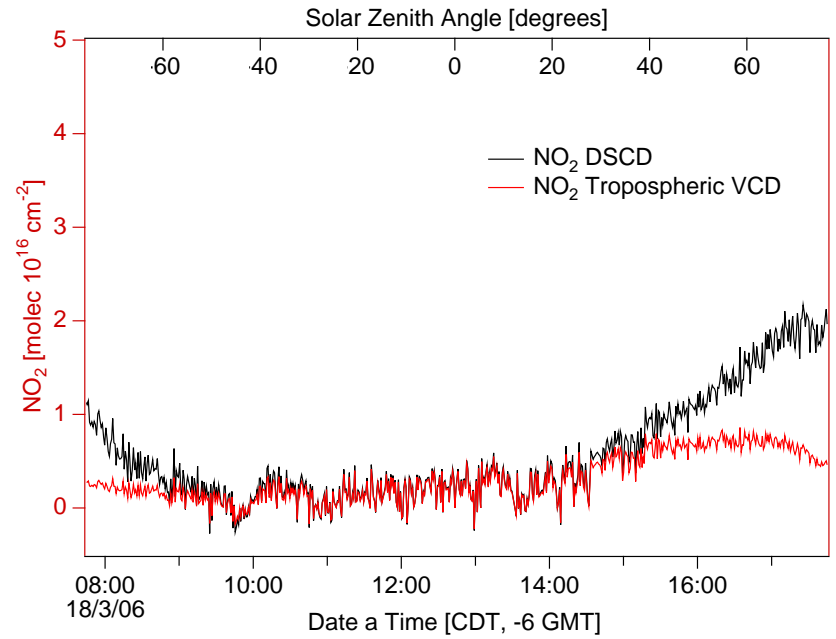

Fig. 2. The $\mathrm{NO}_{2}$ DSCD (black line) is converted to the tropospheric $\mathrm{NO}_{2}$ VCD by applying an AMF of the sec(SZA) in order to account for the increased optical path length of photons as they travel through the stratospheric $\mathrm{NO}_{2}$ layer at large SZA.

tric oxide (NO), $\mathrm{NO}_{\mathrm{x}}$ and reactive nitrogen $\left(\mathrm{NO}_{\mathrm{y}}\right)$ mixing ratios, differential optical absorption spectroscopy (DOAS) tropospheric nitrogen dioxide $\mathrm{NO}_{2}$ vertical column densities (VCD), mixing layer heights (MLH) derived from backscattering ceilometer measurements and meteorological data. Tenango del Aire, located at $19^{\circ} 09^{\prime} 18^{\prime \prime} \mathrm{N}$ and $98^{\circ} 51^{\prime} 50^{\prime \prime} \mathrm{W}$ at $2377 \mathrm{~m}$ (Fig. 1), was the only research site located to the south of Mexico City during the MILAGRO campaign. Winds blew from the city center to the south on many days throughout the campaign (de Foy et al., 2008) making the Tenango del Aire research site an integral part of interpreting the results of the MILAGRO 2006 camaign. We first present an overview of air pollution transportation events through the Tenango del Aire research site using surface $\mathrm{NO}$ and $\mathrm{NO}_{\mathrm{x}}$ mixing ratios, DOAS tropospheric $\mathrm{NO}_{2} \mathrm{VCDs}$ and meteorological data by dividing the data set into three pollution transport case studies. Secondly, the extent of mixing within the mixing layer (ML) in the Mexico City metropolitan area is complex and not well understood (Velasco et al., 2008; Molina et al., 2007; de Foy et al., 2006; Whiteman et al., 2000; Raga et al., 1999). Using the unique data set at the Tenango del Aire research site, we present a new method to study the vertical homogeneity of the ML using DOAS tropospheric $\mathrm{NO}_{2} \mathrm{VCD}$ and ceilometer MLH data in conjunction with surface $\mathrm{NO}_{2}$ mixing ratios. Finally, the impact of natural and anthropogenic pollution sources that reside above the mixing layer (ML) on air quality within the Mexico City metropolitan area remains unknown (Raga et al., 1999; Yokelson et al., 2007). We show DOAS measurements and surface mixing ratios provide a technique to observe pollution sources residing above the ML. The analysis 
presented here shows a more comprehensive analysis of urban air pollution results when a measurement site has both surface and remote sensing instruments.

\section{Instrumentation and data anaylsis}

The Tenango de Aire research site included DOAS measurements of $\mathrm{NO}_{2}$, a ceilometer to determine the MLH, surface meaurements of $\mathrm{NO}, \mathrm{NO}_{\mathrm{x}}, \mathrm{NO}_{\mathrm{y}}$ and surface meteorological data (temperature, humidity, wind direction and wind speed).

\subsection{DOAS instrumentation and method}

Scattered sunlight in the zenith view direction was collected with a small-sized telescope $(2.54 \mathrm{~cm}$ lens with a $10 \mathrm{~cm}$ focal length) connected to a $600 \mu \mathrm{m}$ diameter optical fiber. The optical fiber feeds the collected zenith sky sunlight to an Ocean Optics S2000 Miniature Fiber Optic Spectrometer with a TR-2 Thermoelectric Temperature Regulator. The S2000 is a commercially purchased crossed Czarny-Turner fixed grating spectrometer with a one-dimensional (2048 pixel) charged coupled device (CCD) array, a 1200 line $\mathrm{mm}^{-1}$ grating and a $50 \mu \mathrm{m}$ entrance slit width resulting in an optical resolution of $1.07 \mathrm{~nm}$ full-widthhalf-maximum (FWHM) over the wavelength range from 418 to $731 \mathrm{~nm}$. The maximum integration time was set to $75 \mathrm{msec}$ and decreased automatically to prevent saturation throughout the day reaching a minimum integration time of $3 \mathrm{msec}$. The effect of having a maximum integration time of $75 \mathrm{msec}$ means that during the morning and late afternoon, the signal-to-noise ratio is small because the signal cannot be maximized in $75 \mathrm{msec}$. Thus during the early morning and evening, the detection limit of the spectrometer was reduced. In addition, varying the integration time in order to prevent saturation means the time-resolution of the recorded spectra varies throughout the day increasing as the intensity increases. The acquisition program averages 100 spectra before recording the spectra analyzed in this study.

The visible zenith sky spectra are analyzed using the differential optical absorption spectroscopy (DOAS) method that has been extensively discussed by Noxon (1975); Sanders (1996); Platt and Stutz (2008). The DOAS method uses a Beer-Lambert type of equation to describe the attenuation of radiation by molecular absorbers between a foreground and background spectrum,

$$
\frac{I_{F G}(\lambda)}{I_{B G}(\lambda)}=P(\lambda) \exp \left(-\sum_{i=0}^{m} S_{m}^{\prime} \sigma_{m}^{\prime}(\lambda)\right)
$$

where $I_{F G}(\lambda)$ is the foreground spectrum and $I_{B G}(\lambda)$ is the background spectrum. The background spectrum is typically a noon-time spectrum measured in clear skies and is characterized by the column densities of the absorbers in the nonpolluted atmosphere (the particular background spectrum used in this study is discussed later). The foreground spectrum is a measured spectrum taken at a different time than the background spectrum. The polynomial, $P(\lambda)$, is used to describe the broad molecular absorption features and Rayleigh, aerosol and cloud scattering. The difference in molecular absorption between the foreground and background spectra is given by the sum of the differential molecular absorption cross sections of the species, $\sigma_{m}^{\prime}(\lambda)$, times their differential slant column densities (DSCD), $S_{m}^{\prime}$. To approximately account for the wavelength smoothing performed by the instrument, the molecular absorption cross sections are convolved by the slit function of the spectrometer used to measure the foreground and background spectra. It is important to note that since the background solar spectrum is taken from the ground and not outside the Earth's atmosphere, $S_{m}^{\prime}$, is the difference in the slant column density of the absorber of interest between $I_{F G}(\lambda)$ amd $I_{B G}(\lambda)$ and is not an absolute column measurement.

A critical step in the DOAS method is converting the DSCD to a vertical column density (VCD) by applying an appropriate air mass factor (AMF) that accounts for the increased optical path length through the atmosphere of the foreground spectrum relative to the vertical optical path length (Perliski and Solomon, 1993). In the absence of multiple scattering due to clouds or aerosols, the AMF of $\mathrm{NO}_{2}$ column density measurements for solar zenith angles (SZA) less than $\sim 60^{\circ}$ is the secant of the SZA (Solomon et al., 1987; Perliski and Solomon, 1993).

In the presences of multiple scattering, the retrieval of the oxygen collision complex $\left(\mathrm{O}_{4}\right)$ can provide important information in regards to the optical path length and atmospheric aerosols (Erle et al., 1995; Wagner et al., 1998, 2002, 2004; Pfleilsticker et al., 1999; Pfeilsticker et al., 2001; Wittrock et al., 2004; Sinreich et al., 2005; Heckel et al., 2005; Wang et al., 2005, 2006; Friess et al., 2006; LadstatterWeissenmayer et al., 2007; Melamed et al., 2008, and references therein). The atmospheric $\mathrm{O}_{4}$ mixing ratio is proportional to the square of the oxygen $\left(\mathrm{O}_{2}\right)$ mixing ratio and any non-pressure-related change in the absorption of visible light due to $\mathrm{O}_{4}$ is an indicator of an increased optical path length due to multiple scattering in the atmosphere and not a true enhancement in the amount of $\mathrm{O}_{4}$ in the atmosphere (Perner and Platt, 1979; Greenblatt et al., 1990). It is important to note that since $\mathrm{O}_{4}$ is an $\mathrm{O}_{2}-\mathrm{O}_{2}$ collision complex, the $\mathrm{O}_{4}$ absorption cross section has the units $\mathrm{cm}^{5}$ molecules ${ }^{-2}$. The $\mathrm{O}_{4}$ "column densities" will be expressed with respect to the quadratic $\mathrm{O}_{2}$ concentration in the units molecules $\mathrm{cm}^{-5}$. Since these units are not traditional units for a molecular absorption cross section nor a column density, the $\mathrm{O}_{4}$ quantities will use the symbol DSCD* throughout the text to denote this specialty.

In this study, an AMF of the secant of the SZA is applied to the $\mathrm{NO}_{2}$ DSCDs for SZA less than $60^{\circ}$. The resulting $\mathrm{NO}_{2} \mathrm{VCD}$ represents the tropospheric enhancement in the 


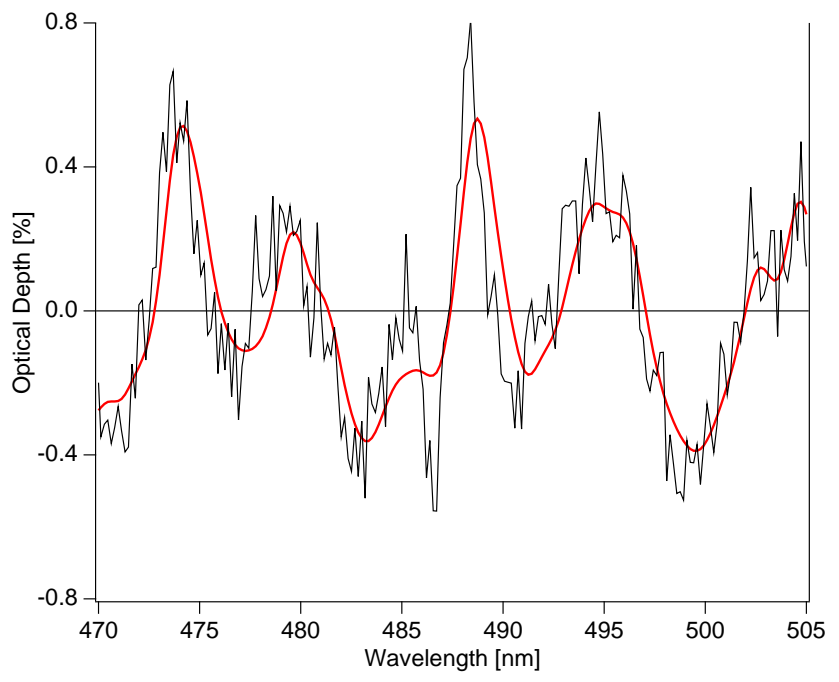

Fig. 3. The retrieved optical depth (red line) and the retrived optical depth plus the residual of the nonlinear least squares fit (black line) of $\mathrm{NO}_{2}$. The $\sim 1 \%$ absorption corresponds to $5.5 \times 10^{16}$ molecules $\mathrm{cm}^{-2}$ measured on 13 March 2008 during Plume 2.

$\mathrm{NO}_{2} \mathrm{VCD}$ due to pollution related events or increases in the optical path length due to multiple scattering by clouds and aerosols. The $\mathrm{O}_{4} \mathrm{DSCD}^{*}$ are then used to qualitatively restrain the source and cause of the tropospheric $\mathrm{NO}_{2} \mathrm{VCD}$ enhancements as discussed in Sects. 3.1, 3.2 and 3.3. This is done by calculating an AMF for $\mathrm{O}_{4}$ according to Melamed et al. (2008), where the $\mathrm{O}_{4} \mathrm{AMF}, A_{\mathrm{O}_{4}}$, is defined as

$A_{\mathrm{O}_{4}}=\frac{S_{\mathrm{O}_{4}}^{*}+S_{B G, \mathrm{O}_{4}}^{*}}{V_{\mathrm{O}_{4}}^{*}}$,

where $S_{\mathrm{O}_{4}}^{\prime *}$ is the retrieved $\mathrm{O}_{4} \mathrm{DSCD}^{*}, S_{B G, \mathrm{O}_{4}}^{*}$ is the calculated $\mathrm{O}_{4} \mathrm{SCD}^{*}$ in the background spectrum and $V_{\mathrm{O}_{4}}^{*}$ is the calculated $\mathrm{O}_{4} \mathrm{VCD}^{*}$ at the Tenango del Aire research site. If the vertical distribution of $\mathrm{NO}_{2}$ and $\mathrm{O}_{4}$ were identical then the $\mathrm{O}_{4}$ AMF could be applied to the retrieved $\mathrm{NO}_{2}$ DSCDs. However, since the vertical profiles of $\mathrm{NO}_{2}$ and $\mathrm{O}_{4}$ differ, in this study the $\mathrm{O}_{4} \mathrm{AMF}$ is used to qualitatively restrain the interpretation of the enhancements of the $\mathrm{NO}_{2}$ VCDs.

$\mathrm{NO}_{2}$ DSCDs are retrieved in the visible spectral window of $470-505 \mathrm{~nm}$. In addition to $\mathrm{NO}_{2}$, the other atmospheric absorbers included in the retrieval are $\mathrm{O}_{3}$ and $\mathrm{O}_{4}$. The highresolution laboratory absorption cross section for $\mathrm{O}_{3}$ at $223 \mathrm{~K}$ (Voigt et al., 2001), $\mathrm{O}_{4}$ at $296 \mathrm{~K}$ (Greenblatt et al., 1990) and $\mathrm{NO}_{2}$ at $293 \mathrm{~K}$ (Voigt et al., 2002) are convolved to the instrument resolution for use in Eq. (1). The analysis also includes a Ring cross section (Grainger and Ring, 1962) derived according to Melamed et al. (2008) from the Kurucz et al. (1984) solar spectrum. A "shift and stretch" is applied in order to align the laboratory cross sections acquired by a different spectrometer at different temperatures and air den- sities with the foreground spectra. The broad absorption and attenuation features are accounted for by including a second order polynomial. The DOAS shift, stretch, polynomial coefficients and DSCDs are solved for using the LevenbergMarquardt nonlinear least squares fitting algorithm (Levenberg, 1944; Marquardt, 1963). An example $\mathrm{NO}_{2}$ DOAS retrieval is shown in Fig. 3. The estimated detection limit for the $\mathrm{NO}_{2}$ retrievals is $2.50 \times 10^{15}$ molecules $\mathrm{cm}^{-2}$, assuming the intensity of the photons reaching the spectrometer is maximized, and the estimated error in the retrievals is $\pm 1.50 \times 10^{15}$ molecules $\mathrm{cm}^{-2}$.

The same background spectrum was used for the entire campaign and was taken on 18 March 2006 at 12:43 p.m. CDT when the SZA was the lowest for the entire day at $20^{\circ}$. This background spectrum was chosen because it was taken under clear skies at a low SZA and when the surface $\mathrm{NO}_{2}$ mixing ratio was small, $1.5 \mathrm{ppbv}$. The stratospheric $\mathrm{NO}_{2}$ column density on 18 March 2006 derived from SCIAMACHY limb satellite data (A. Richter, personal communication, 2009) at 10:00 CDT was $2.5 \times 10^{15}$ molecules $\mathrm{cm}^{-2}$. Thus the background spectrum chosen in this analysis accounts for this $\mathrm{NO}_{2}$ stratospheric column and the DSCDs presented below are enhancements due to an increase in the tropospheric $\mathrm{NO}_{2}$ column density or an enhanced path length through the atmosphere due to changes in SZA and multiple scattering due to clouds and aerosol. Throughout the measurement period, the stratospheric $\mathrm{NO}_{2}$ column density measured by SCIAMACHY varied from 2.08 to $2.87 \times 10^{15}$ molecules $\mathrm{cm}^{-2}$. In addition, the diurnal variation of stratospheric $\mathrm{NO}_{2}$ at $28^{\circ} \mathrm{N}$ has been shown to be on the order of $1.4 \times 10^{15}$ molecules $\mathrm{cm}^{-2}$ (Gil et al., 2008) and we assume a similar diurnal variation in stratospheric $\mathrm{NO}_{2}$ above Mexico City. Although the influence of the stratospheric $\mathrm{NO}_{2}$ layer is small on the large $\mathrm{NO}_{2}$ enhancements presented in this study, it provides another source of error in the DOAS measurements.

The $\mathrm{O}_{4}$ DSCD* $^{*} \mathrm{~s}$ are retrieved in a similar wavelength region as the $\mathrm{NO}_{2}$ retrievals since photons in different wavelength regions can exhibit different optical path lengths (Solomon et al., 1987; Platt et al., 1997). The $\mathrm{O}_{4}$ DSCD*s are $^{*}$ retrieved in the $460-490 \mathrm{~nm}$ wavelength region. The $\mathrm{O}_{4}$ retrievals include the following: a "shift and stretch", a second order polynomial and the Ring, $\mathrm{NO}_{2}$ and $\mathrm{O}_{3}$ cross sections used in the $\mathrm{NO}_{2}$ retrievals. The same background spectrum that was used in the $\mathrm{NO}_{2}$ DOAS retrievals is used for the $\mathrm{O}_{4}$ retrievals. An example $\mathrm{O}_{4}$ DOAS retrieval is shown in Fig. 4. The estimated detection limit under a maximum signal is $2.0 \times 10^{42}$ molecules $\mathrm{cm}^{-5}$ and the estimated error in the $\mathrm{O}_{4}$ DOAS retrievals is $\pm 1.06 \times 10^{42}$ molecules $^{2} \mathrm{~cm}^{-5}$.

\subsection{Ceilometer instrument and analysis}

The ceilometer is a Vaisala double-lens ceilometer (Münkel et al., 2004). It measures the optical attenuated backscatter intensity at $0.855 \mu \mathrm{m}$ averaged over $15 \mathrm{~s}$. This special 
wavelength has been chosen because the absorption by water vapor is much lower here than at $0.910 \mu \mathrm{m}$; a wavelength for which laser diodes are easily available. $0.885 \mu \mathrm{m}$ would have been ideal but no laser diodes were available for this wavelength. The typical vertical range of this instrument is $4000 \mathrm{~m}$; the vertical resolution is $7.5 \mathrm{~m}$. Apart from the very strong backscatter from clouds (that is what the instrument had originally been designed for) and fog, weaker gradients in the backscatter intensity are mainly determined by the number and the size spectrum of aerosol particles floating in the air. Reliable analysis of the vertical profile of particle-induced backscatter can be made from heights above $\sim 140 \mathrm{~m}$. Below that height the overlap between the emitted beam and the field-of-view of the receiver is smaller than $30 \%$. The overlap is zero for heights below $60 \mathrm{~m}$. Any signal received from distances below $60 \mathrm{~m}$ is generated by multiple scattering and scattering of light at dust and dirt particles on the weather protection glass of the transmitter into the field-of-view of the receiver. A slight contamination of the glass thus results in a signal amplitude decrease for distances above $60 \mathrm{~m}$, but a signal amplitude increase for distances below $60 \mathrm{~m}$ (Emeis et al., 2007).

The MLH is retrieved using a refined approach of the retrieval by Schäfer et al. (2004), which is described in detail by Emeis et al. (2007). This retrieval algorithm is based on an analysis of the minima of the vertical gradients of the aerosol backscatter intensity (i.e. the greatest decreases in the backscatter intensity with height) recorded by the ceilometer.

Prior to the determination of gradient minima the overlap and range corrected attenuated backscatter profiles have to be averaged over time and height to suppress noise generated artifacts. Between $140 \mathrm{~m}$ and $500 \mathrm{~m}$ height sliding averaging is done over $15 \mathrm{~min}$ and a height interval $\Delta h$ of $80 \mathrm{~m}$. In the layer between 500 and $2000 \mathrm{~m} \Delta h$ for vertical averaging is extended to $160 \mathrm{~m}$. Two additional parameters have been introduced to further reduce the number of false hits. The minimum accepted attenuated backscatter intensity right below a lifted inversion is set to $200 \times 10^{-9} \mathrm{~m}^{-1} \mathrm{sr}^{-1}$ in the lower layer and $250 \times 10^{-9} \mathrm{~m}^{-1} \mathrm{sr}^{-1}$ in the upper layer. Additionally the vertical gradient value of a lifted inversion must be more negative than $-0.30 \times 10^{-9} \mathrm{~m}^{-1} \mathrm{sr}^{-1}$ in the lower layer and more negative than $-0.30 \times 10^{-9} \mathrm{~m}^{-1} \mathrm{sr}^{-1}$ in the upper layer.

If $B(z)$ denotes the measured attenuated backscatter intensity in the height $z$ above ground averaged over time and height and $\Delta h$ is the height averaging interval, then a gradient minimum is characterized by a change of sign from minus to plus of the second derivative of $B(z)$. The height interval under examination is searched from bottom to top for these gradient minima. There is a gradient minimum in the height $z$ if the second derivative of $B(z)$ one range gate below $z$ is not positive, if the second derivative of $B(z)$ in the height $z$ is positive and if the false hit conditions mentioned above are fulfilled. The MLH from optical remote sensing is taken as the lowest height found by this procedure.

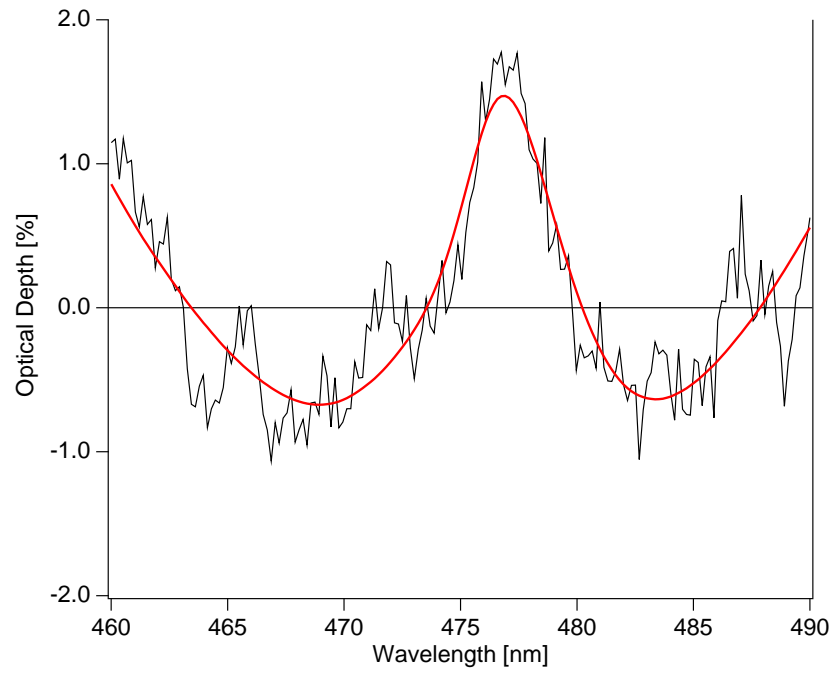

Fig. 4. The retrieved optical depth (red line) and the retrived optical depth plus the residual of the nonlinear least squares fit (black line) of $\mathrm{O}_{4}$. The $\sim 2 \%$ absorption corresponds to $4.7 \times 10^{43}$ molecules $^{2} \mathrm{~cm}^{-5}$ measured on 28 March 2008 during a thunderstorm. Please note $\mathrm{O}_{4}$ is an $\mathrm{O}_{2}-\mathrm{O}_{2}$ collision complex and therefore the retrieved $\mathrm{O}_{4}$ values are reported with respect to the quadratic of the $\mathrm{O}_{2}$ concentrations in units molecules $\mathrm{cm}^{2}$.

The retrieval algorithm for MLH fails in case of strong mist and fog and especially during rainfall because then the backscatter intensity is determined by the water or rain droplets only.

\subsection{Surface mixing ratio measurements}

$\mathrm{NO}, \mathrm{NO}_{\mathrm{x}}$ and $\mathrm{NO}_{\mathrm{y}}$ surface mixing ratios were measured using a TEI 42C chemiluinescence monitor (Thermo Scientific www.thermo.com) with several monitoring ranges spanning from $0-5 \mathrm{ppbv}$ and from $0-200 \mathrm{ppbv}$ with a linearity of $+/-1 \%$ of full scale reading. The lower detectable mixing ratio is 0.4 ppbv NO for all three species. When in $\mathrm{NO}_{\mathrm{y}}$ mode, an additional Mo catalitic converter is used on top of the mobile unit and a short PFA Teflon inlet was used to mimize wall losses of nitric acid, $\mathrm{HNO}_{3}$. Oxidized $\mathrm{N}$ species are converted to $\mathrm{NO}$ by a molybdenum $\mathrm{NO}_{2}$-to-NO converter heated to about $325^{\circ} \mathrm{C}$ and measured as such in the TEI $42 \mathrm{C}$ instrument (McClenny, 2000).

In the following analysis, the surface $\mathrm{NO}_{2}$ mixing ratio is inferred from the $\mathrm{NO}_{\mathrm{x}}$ and $\mathrm{NO}$ measurements $\left(\left[\mathrm{NO}_{2}\right]=\left[\mathrm{NO}_{\mathrm{x}}\right]-[\mathrm{NO}]\right)$. However, commercial $\mathrm{NO}_{\mathrm{x}}$ chemiluinescence monitors with a molybdenum converter are able to partially reduce more oxidized nitrogen compound $\left(\mathrm{HNO}_{3}, \mathrm{HONO}, \mathrm{PAN}, \mathrm{PPN}\right)$. Therefore, the $\mathrm{NO}_{2}$ mixing ratio inferred from the above equation in this study is an upper limit dependent on the catalyst design and temperature, input pipe length and photochemical age of the polluted air parcel being observed. On 21 March the $\mathrm{NO}$ and $\mathrm{NO}_{\mathrm{x}}$ 


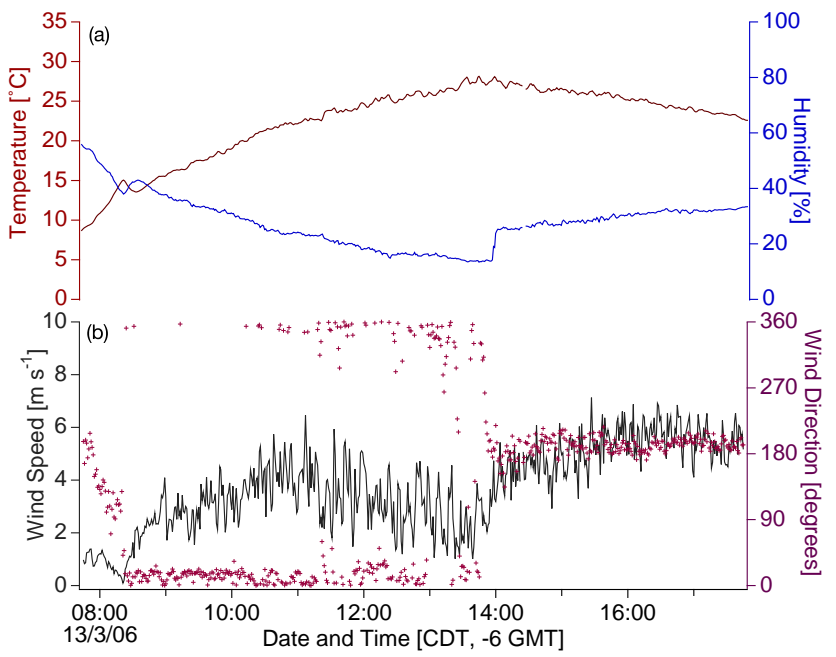

Fig. 5. Meteorological condition for 13 March 2006 at Tenango del Aire (a) air temperature and relative humidity and (b) wind speed and wind direction.

surface instrument switched to measuring $\mathrm{NO}_{\mathrm{y}}$ and therefore the surface mixing ratio of $\mathrm{NO}_{2}$ could not be inferred after this date.

\section{Results and discussion}

The Tengango del Aire data set is divided into three case studies based on surface wind direction, surface $\mathrm{NO}_{2}$ and $\mathrm{NO}_{\mathrm{y}}$ mixing ratios and DOAS tropospheric $\mathrm{NO}_{2} \mathrm{VCD}$ measurements as shown in Table 1. The three different cases are then compared with the basin-scale wind analysis conducted by de Foy et al. (2008).

Case 1 days are dominated by northerly winds during the morning. Since the research site is located to the southeast of the city center, the surface mixing ratio and DOAS measurements detect various pollution plumes being transported through the research site when northerly winds exist. On the majority of the Case 1 days, the wind direction shifts midto late-afternoon from northerly to southerly. According to the basin-scale wind transport analysis conducted by de Foy et al. (2008), the Case 1 days are classified as South Venting (SV), $\mathrm{O}_{3}$-South $\left(\mathrm{O}_{3} \mathrm{~S}\right)$, or Cold Surge (CS) episodes. SV, $\mathrm{O}_{3} \mathrm{~S}$ and CS days were all dominated by northerly winds.

Case 2 days are all dominated by southerly winds. The surface mixing ratio and DOAS $\mathrm{NO}_{2}$ measurements do not detect any significant increase in $\mathrm{NO}_{2}$ throughout these days as the air to the south of the Tenango del Aire research site is relatively clean. The majority of Case 2 days are classified as $\mathrm{O}_{3}$-North $\left(\mathrm{O}_{3} \mathrm{~N}\right)$ episodes, which are dominated by southerly winds throughout the entire day, (de Foy et al., 2008).

Case 3 days exhibit mainly southerly winds but the wind direction tends to be more variable throughout the day com- pared to the Case 1 and Case 2 days. In the mornings, the surface mixing ratio and DOAS $\mathrm{NO}_{2}$ measurements do not detect any significant increase in air pollution. However, in the afternoon, the DOAS measurements observe large enhancements in the tropospheric $\mathrm{NO}_{2} \mathrm{VCD}$ while the surface $\mathrm{NO}$, $\mathrm{NO}_{\mathrm{x}}$ and $\mathrm{NO}_{\mathrm{y}}$ mixing ratios show no corresponding increase. Case 3 days are classified as "convection-north" (CNVN) or "convection-south" (CNVS) episodes that are characterized by mostly clear skies in the morning, followed by afternoon showers and exhibited either a stronger north or south transport in the afternoon (de Foy et al., 2008).

In the following three sections, an example day from each case is analyzed in depth and the importance of having both surface mixing ratio and remote sensing measurements at urban air pollution research sites to gain a more comprehensive understanding of air pollution is discussed. DOAS measurements are dependent on sufficient sunlight to make mesurements. Therefore, the following days are analyzed from 07:45 to 17:45 local time (CDT) in order to analyze pollution transport events when DOAS measurements were available. It should be noted that all DOAS $\mathrm{NO}_{2}$ enhancements in the following analysis occur when the SZA is less than $60^{\circ}$ and thus the use of the secant of the SZA, in the absence of multiple scattering as determined by the $\mathrm{O}_{4} \mathrm{AMF}$, is valid.

\subsection{Case 1 - 13 March 2006}

A typical Case 1 day is 13 March 2006. On this day, northerly surface winds persist at Tenango del Aire between 08:00 and 14:00 CDT. At 14:00 CDT, the wind direction changes to southerly (Fig. 5). During the six hour period of northerly winds, the surface $\mathrm{NO}_{2}$ measurements indicate three distinct plumes transported through the research site (Fig. 6). When the wind direction changes to southerly at 14:00 CDT, the surface $\mathrm{NO}_{2}$ mixing ratio decreases and the humidity increases as relatively clean air from the south is transported through the Tenango del Aire research site.

The first $\mathrm{NO}_{2}$ plume occurred early in the morning from 07:43 to $08: 42 \mathrm{CDT}$ and had a maximum surface $\mathrm{NO}_{2}$ mixing ratio of $29 \mathrm{ppbv}$. The average wind direction during plume 1 was $95 \pm 69^{\circ}$ due to a shift in the wind direction as the plume passed through the research site. The average wind speed was $1.1 \pm 0.5 \mathrm{~m} \mathrm{~s}^{-1}$. The mixing layer height (MLH) is low during this Plume 1 with an average height of $312 \pm 7 \mathrm{~m}$. If the ML was completely mixed and the intensity of the photons reaching the spectrometer was maximized, the tropospheric $\mathrm{NO}_{2} \mathrm{VCD}$ would be $1.7 \times 10^{16}$ molecules $\mathrm{cm}^{-2}$ and should be detected by the DOAS instrument. However, the DOAS $\mathrm{NO}_{2}$ measurements do not detect the first plume due to a combination of two possible factors. The first factor is that the maximum integration time was limited to $75 \mathrm{msec}$. With a large SZA during Plume $1,64^{\circ}$ to $75^{\circ}$, the amount of light reaching the spectrometer was small, resulting in a very low signal-to-noise ratio. The second factor is it is 
Table 1. Tenango del Aire days by case.

\begin{tabular}{|c|c|c|c|c|c|c|c|c|c|}
\hline Date $^{1}$ & Case 1 & Case 2 & Case 3 & SV & $\mathrm{O}_{3} \mathrm{~S}$ & $\mathrm{O}_{3} \mathrm{~N}$ & CS & CNVS & CNVN \\
\hline 2 & X & & & X & & & & & \\
\hline 3 & X & & & $\mathrm{X}$ & & & & & \\
\hline 4 & X & & & X & & & & & \\
\hline 5 & $X$ & & & X & & & & & \\
\hline 6 & $X$ & & & X & & & & & \\
\hline 7 & X & & & $\mathrm{X}$ & & & & & \\
\hline 8 & & X & & & X & & & & \\
\hline 9 & & X & & & & X & & & \\
\hline 10 & & X & & & & X & & & \\
\hline 11 & & X & & & & $\mathrm{X}$ & & & \\
\hline 12 & X & & & & X & & & & \\
\hline 13 & X & & & X & & & & & \\
\hline 14 & X & & & & & & X & & \\
\hline 15 & X & & & & X & & & & \\
\hline 16 & X & & & & X & & & & \\
\hline 17 & X & & & & $\mathrm{X}$ & & & & \\
\hline 18 & & X & & & & X & & & \\
\hline 19 & & X & & & & $\mathrm{X}$ & & & \\
\hline 20 & & X & & & & X & & & \\
\hline 21 & X & & & & & & $\mathrm{X}$ & & \\
\hline 22 & & X & & & & X & & & \\
\hline 23 & X & & & & & & X & & \\
\hline 24 & & X & & & & & & X & \\
\hline 25 & & $\mathrm{X}$ & & & & & & X & \\
\hline 26 & & & $\mathrm{X}$ & & & & & X & \\
\hline 27 & & X & & & & & & & $X$ \\
\hline 28 & & & X & & & & & & $X$ \\
\hline 29 & & & X & & & & & & $X$ \\
\hline 30 & & & X & & & & & & $X$ \\
\hline 31 & & & $\mathrm{X}$ & & & & & $X$ & \\
\hline
\end{tabular}

$\mathrm{SV}=$ South Venting, $\mathrm{O}_{3} \mathrm{~S}=\mathrm{O}_{3}-$ South $; \mathrm{O}_{3} \mathrm{~N}=\mathrm{O}_{3}-\mathrm{North} ; \mathrm{CS}=$ Cold Surge; CNVS = Convection-South; CNVN = Convection-North (de Foy et al., 2008).

${ }^{1}$ Day of month for March 2006

assumed $\mathrm{NO}_{2}$ has a strong source at the ground and in the early morning, mixing of the ML is limited due to a small amount of convective mixing and low horizontal wind speeds of $1.0 \mathrm{~m} \mathrm{~s}^{-1}$. It is likely Plume 1 is a thin low lying $\mathrm{NO}_{2}$ layer that has a high surface mixing ratio of 29 ppbv but a small tropospheric column density. Therefore, Plume 1 is not observed by the DOAS measurements due to a combination of these two factors.

A second Plume from the north was transported through the Tenango del Air research site from 09:13 to 10:34 CDT. The average wind direction during Plume 2 was $12 \pm 8^{\circ}$ and the average wind speed was $3.3 \pm 0.8 \mathrm{~m} \mathrm{~s}^{-1}$. The maximum surface $\mathrm{NO}_{2}$ mixing ratio was $30 \mathrm{ppbv}$. With increased surface temperatures, convective mixing increases and the MLH during Plume 2 increasing from $300 \mathrm{~m}$ to $500 \mathrm{~m}$. Plume 2 is detected in the DOAS measurements due to an increase in the intensity of the photons reaching the spectrometer and an increase in the total $\mathrm{NO}_{2}$ molecules in the atmosphere. As can be seen in Fig. 6, the tropospheric $\mathrm{NO}_{2}$ VCD reaches a maximum of $1.7 \times 10^{16}$ molecules $\mathrm{cm}^{-2}$.

A third $\mathrm{NO}_{2}$ plume is transported through the Tenango del Aire research site from 10:45 to 11:58 CDT. The average wind direction during Plume 3 was still out of the north at $4 \pm 18^{\circ}$ and the average wind speed was $3.8 \pm 1.0 \mathrm{~m} \mathrm{~s}^{-1}$. During the passage of Plume 3, the MLH continued to increase to $1200 \mathrm{~m}$ and the maximum surface $\mathrm{NO}_{2}$ mixing ratio was 32 ppbv. The DOAS tropospheric $\mathrm{NO}_{2} \mathrm{VCD}$ reaches a maximum column density of $4.8 \times 10^{16}$ molecules $\mathrm{cm}^{-2}$.

After Plume 3, a smaller enhancement in the surface $\mathrm{NO}_{2}$ mixing ratio and tropospheric $\mathrm{NO}_{2} \mathrm{VCD}$ was observed. At 14:00 CDT when southerly winds dominated, both the surface mixing ratio and the tropospheric $\mathrm{VCD}$ of $\mathrm{NO}_{2}$ decreased as relatively clean air was transported to the research site from the south. The winds were southerly for the rest of the day and no enhancements in the surface nor the DOAS $\mathrm{NO}_{2}$ measurements were detected. The surface $\mathrm{NO}_{2}$ 


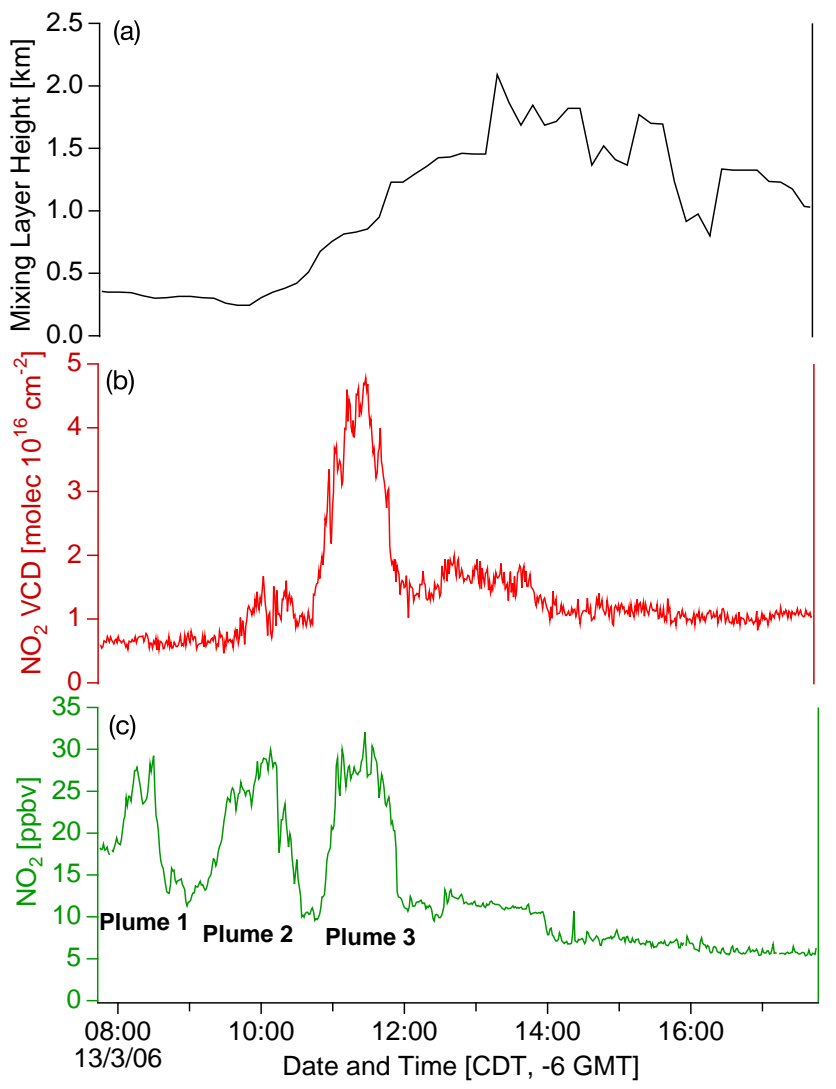

Fig. 6. Measurements of (a) ceilometer mixing layer height (b) tropospheric $\mathrm{NO}_{2}$ vertical column densities and (c) surface $\mathrm{NO}_{2}$ mixing ratios on 13 March 2006. Plumes 1, 2 and 3 indicated three distinct $\mathrm{NO}_{2}$ plumes that passed through the Tenango del Aire research site during the morning on 13 March 2006.

mixing ratios indicated a background level $\mathrm{NO}_{2}$ mixing ratio of $6.6 \pm 0.8 \mathrm{ppbv}$.

A comparison between Plume 2 and Plume 3 highlights the difference between surface and column density measurement and the importance of having both measurement techniques at an urban research site. The DOAS measurements show that between Plume 2 and Plume 3, the total tropospheric $\mathrm{NO}_{2} \mathrm{VCD}$ increases from $1.7 \times 10^{-16}$ molecules $\mathrm{cm}^{-2}$ to $4.8 \times 10^{-16}$ molecules $\mathrm{cm}^{-2}$. However, the maximum surface $\mathrm{NO}_{2}$ mixing ratio stayed more or less equal, $29 \mathrm{ppbv}$ during Plume 2 and $32 \mathrm{ppbv}$ during Plume 3. This is a consequence of mainly two processes: (1) the $\mathrm{NO}_{2}$ molecules occupy more space due to an increase in MLH and (2) with on-going surface emissions into a larger air volume and a decomposition of atmospheric nitrogen strong compounds such as PAN in the warmer atmosphere around noon, the total amount of the target molecules in the volume increase but the mole fraction of $\mathrm{NO}_{2}$ near the ground stays more or less constant.

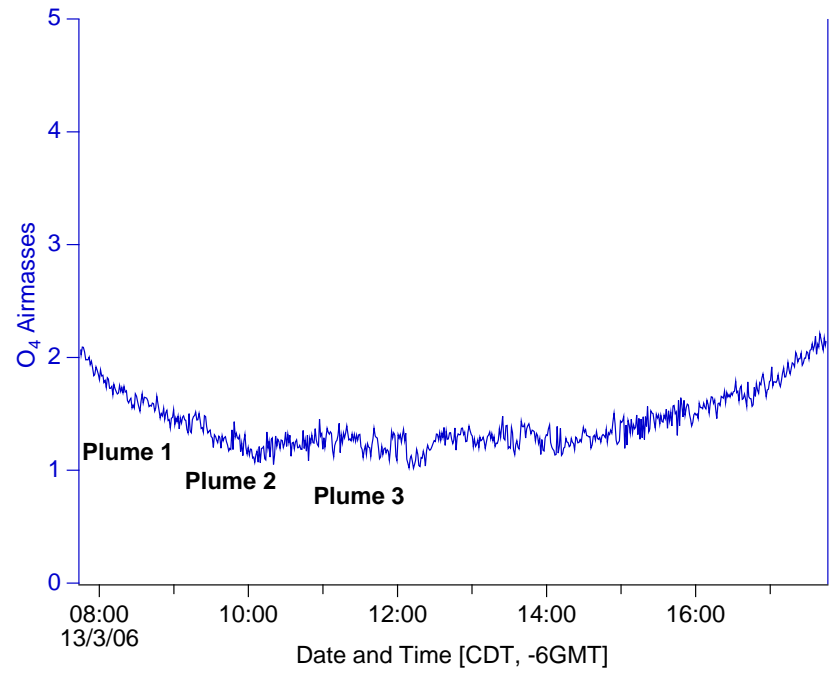

Fig. 7. The $\mathrm{O}_{4}$ AMF for 13 March 2006. Plume 1, Plume 2 and Plume 3 represent the time period in which the $\mathrm{NO}_{2}$ plumes passed through the Tenango del Aire research site on the morning of 13 March 2006.

The $\mathrm{O}_{4}$ AMF did not significantly increase during Plume 2 nor Plume 3 indicating the enhancements seen in the tropospheric DOAS $\mathrm{NO}_{2} \mathrm{VCD}$ are due to an increase in pollution rather than an increased optical path length caused by multiple scattering by aerosols or clouds (Fig. 7). Due to the fact that the $\mathrm{O}_{4}$ AMF does not detect an increased optical path length due to multiple scattering throughout the day, an AMF of the secant of the SZA was applied to the $\mathrm{NO}_{2}$ DSDS on this day for $\mathrm{SZA} \leq 60^{\circ}$.

Using the MLH from the ceilometer data, the tropospheric $\mathrm{NO}_{2} \mathrm{VCD}$ can be used to estimate a mixing ratio,

$\mathrm{NO}_{2}(\mathrm{ppbv})=\frac{\mathrm{NO}_{2} \mathrm{VCD}^{*} 1 \mathrm{e} 9}{\bar{A} Z_{B}}$,

where $\mathrm{NO}_{2} \mathrm{VCD}$ is the measured tropospheric $\mathrm{NO}_{2} \mathrm{VCD}$ in molecules $\mathrm{cm}^{-2}, \bar{A}$ is the average number of air molecules in the ML in molecules $\mathrm{cm}^{-3}$ and $Z_{B}$ is the MLH in $\mathrm{cm}$. If the ML is vertically homogeneous and the tropospheric $\mathrm{NO}_{2}$ VCD enhancement is located within the well mixed ML, then the calculated DOAS $\mathrm{NO}_{2}$ mixing ratio should equal the surface $\mathrm{NO}_{2}$ mixing ratio. If the measured surface mixing ratio and the estimated DOAS mixing ratio are not equal, then either the ML is not vertically homogeneous and/or the $\mathrm{NO}_{2}$ molecules measured by DOAS may not reside in the ML. Using Eq. (3), the DOAS tropospheric $\mathrm{NO}_{2} \mathrm{VCD}$ is converted to a mixing ratio for Plumes 2 and 3 . Figure 8 shows the measured surface and the calculated $\mathrm{NO}_{2}$ mixing ratios. The comparison between the measured and estimated $\mathrm{NO}_{2}$ mixing ratios indicate that as Plume 2 passes through the research site, the ML becomes vertically homogeneous and by late morning the ML is well mixed as seen in Plume 3. In 


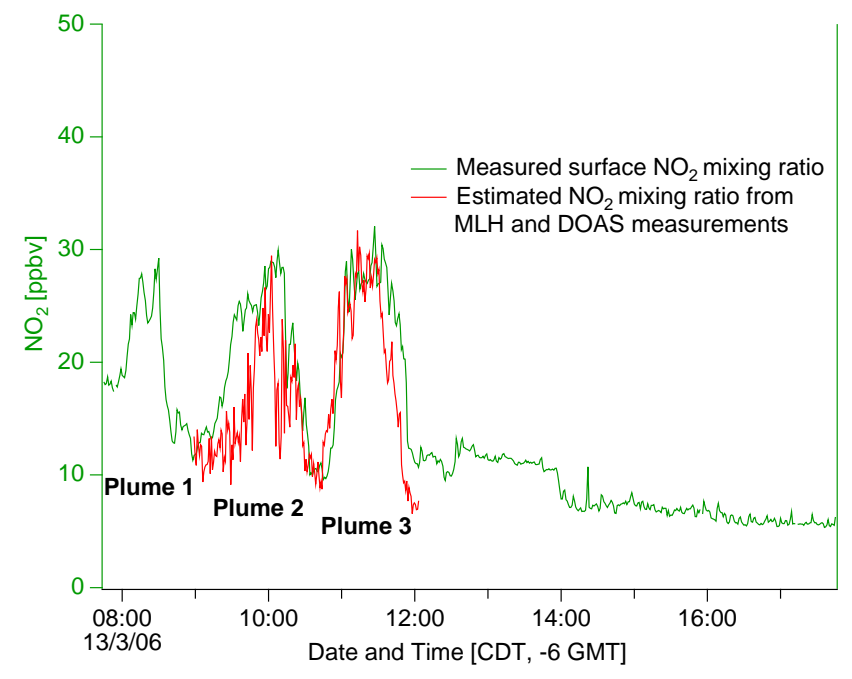

Fig. 8. A comparison of measured surface $\mathrm{NO}_{2}$ mixing ratios (green line) to estimated DOAS $\mathrm{NO}_{2}$ mixing ratios (red line) in ppbv for Plume 2 and Plume 3 on 13 March 2006.

addition, the agreement between the measured and estimated $\mathrm{NO}_{2}$ mixing ratios support the conclusion that the $\mathrm{NO}_{2} \mathrm{VCD}$ observed by DOAS instrument resides within the ML.

\subsection{Case 2 - 18 March 2006}

18 March 2006 represents a Case 2 day, which was dominated by southerly winds and no significant enhancements in surface mixing ratio nor tropospheric VCDs of $\mathrm{NO}_{2}$ were observed. On this day at the Tenango del Aire research site, the average wind direction was from the south at $191 \pm 25^{\circ}$ from 07:45 to 17:45 CDT. The wind speed was rather constant with an average of $5.2 \pm 1.6 \mathrm{~m} \mathrm{~s}^{-1}$ (Fig. 9). As shown on the analysis of 13 March 2006, when the winds are from the south, the air passing through the Tenango del Aire research site is relatively clean. Figure 10 supports this conclusion indicating the average surface $\mathrm{NO}_{2}$ mixing ratio for the entire days was $2.9 \pm 1.9 \mathrm{ppbv}$ and never reached above 12 ppbv. Between 07:45 and 09:45 CDT two small plumes can be identified in the surface $\mathrm{NO}_{2}$ measurements. These low lying plumes are likely plumes either from Mexico City or from other urban areas to the south or southwest being transported through the Tenango del Aire research site as the wind direction shifted. In addition, throughout the day the surface measurements show narrow $\mathrm{NO}_{2}$ enhancements. The source of the $\mathrm{NO}_{2}$ in these peaks is most likely local and would not create any change in the tropospheric $\mathrm{NO}_{2} \mathrm{VCD}$. Therefore, the tropospheric $\mathrm{NO}_{2} \mathrm{VCD}$ measurements show no enhancements throughout the entire day.

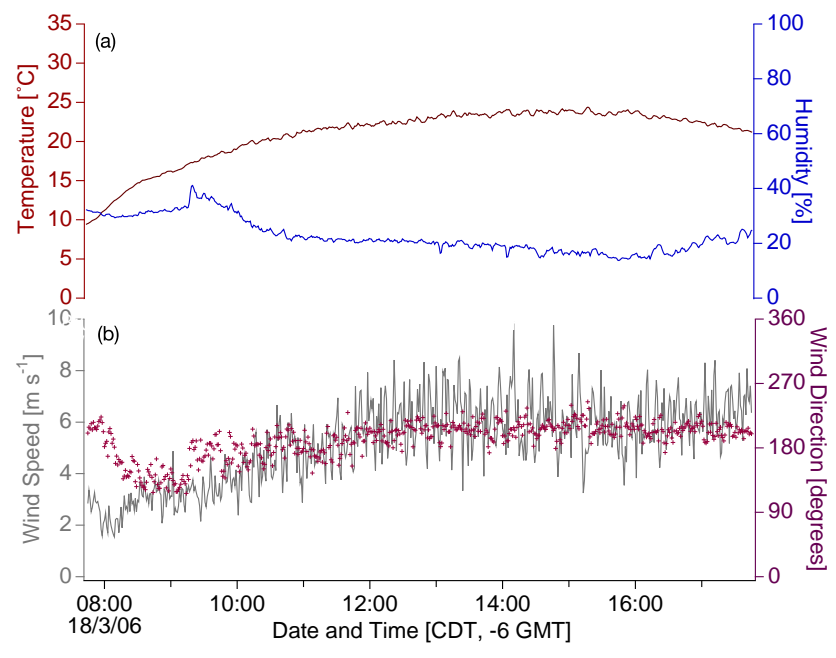

Fig. 9. Meteorological condition for 18 March 2006 at Tenango del Aire (a) air temperature and relative humidity and (b) wind speed and wind direction.

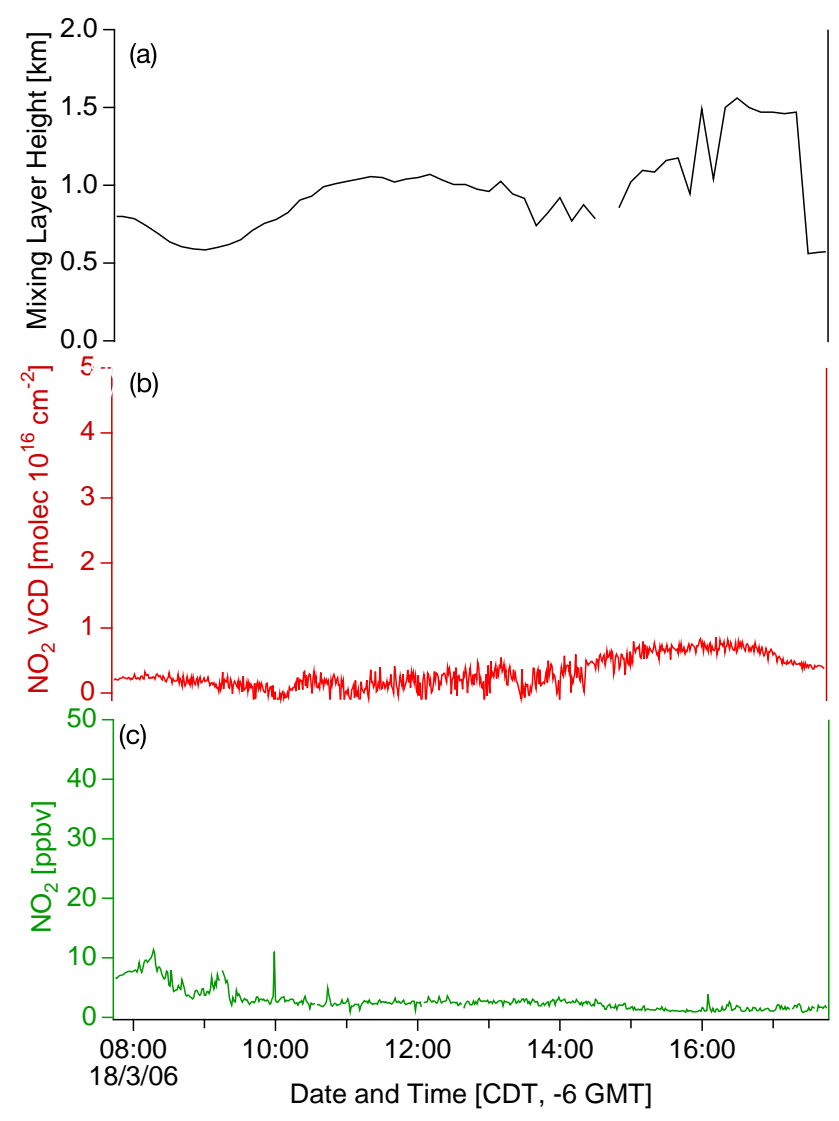

Fig. 10. Measurements of (a) ceilometer mixing layer height (b) tropospheric $\mathrm{NO}_{2}$ vertical column densities and (c) surface $\mathrm{NO}_{2}$ mixing ratios on 18 March 2006. 


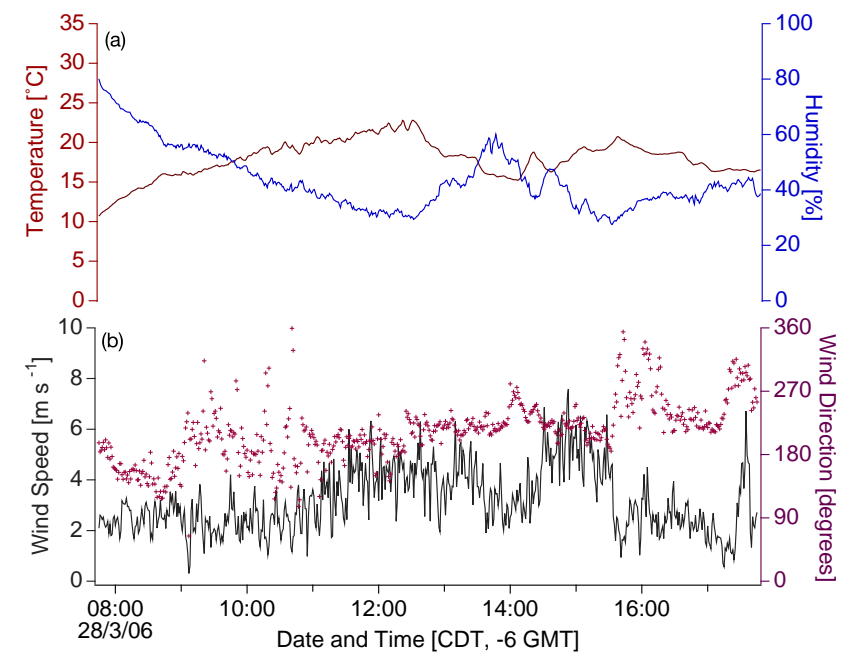

Fig. 11. Meteorological condition for 28 March 2006 at Tenango del Aire (a) air temperature and relative humidity and (b) wind speed and wind direction.

\subsection{Case 3-28 March 2006}

Case 3 days are classified by de Foy et al. (2008) as either CNVN or CNVS days, depending on the stronger component of transport in the late afternoon. These days occurred after humid conditions from a cold surge on 23 March 2006 persisted, leading to afternoon convection and rainfall (de Foy et al., 2008). Based on the meteorological data and the surface $\mathrm{NO}_{\mathrm{y}}$ measurements, a Case 3 day appears to be very similar to a Case 2 day in that the dominant wind direction is from the south and no major enhancements were observed in the surface $\mathrm{NO}_{\mathrm{y}}$ measurements. The large difference is that on all Case 3 days significant enhancements in the tropospheric $\mathrm{NO}_{2} \mathrm{VCD}$ were observed in the afternoon that were not detected by the surface mixing ratio measurements.

An example Case 3 day is 28 March 2006, a CNVS day. On this day the average wind direction was from the southwest at $212 \pm 43^{\circ}$ and the average wind speed was $3.2 \pm 1.3 \mathrm{~m} \mathrm{~s}^{-1}$ (Fig. 11). The surface $\mathrm{NO}_{\mathrm{y}}$ mixing ratio measurements show no significant plumes throughout the day except for a low layer passing through the research site in the morning that coincides with the change in the wind direction in the morning from northerly to southerly, which was also observed on 13 and 18 March (Fig. 12). Two enhancements in the tropospheric $\mathrm{NO}_{2} \mathrm{VCD}$ were detected in the afternoon, a large one from 12:50 to 14:50 CDT followed by a smaller one from 13:00 to 16:20 CDT (Fig. 12). Neither of these enhancements were detected in the surface $\mathrm{NO}_{\mathrm{y}}$ mixing ratio measurements. The following analysis will show that the tropospheric $\mathrm{NO}_{2} \mathrm{VCD}$ enhancements were likely due to a combination of an increased optical path length from multiple scattering within a cloud and an increase in $\mathrm{NO}_{2}$ due to lightning (Erle et al., 1995; Pfleilsticker et al., 1999).

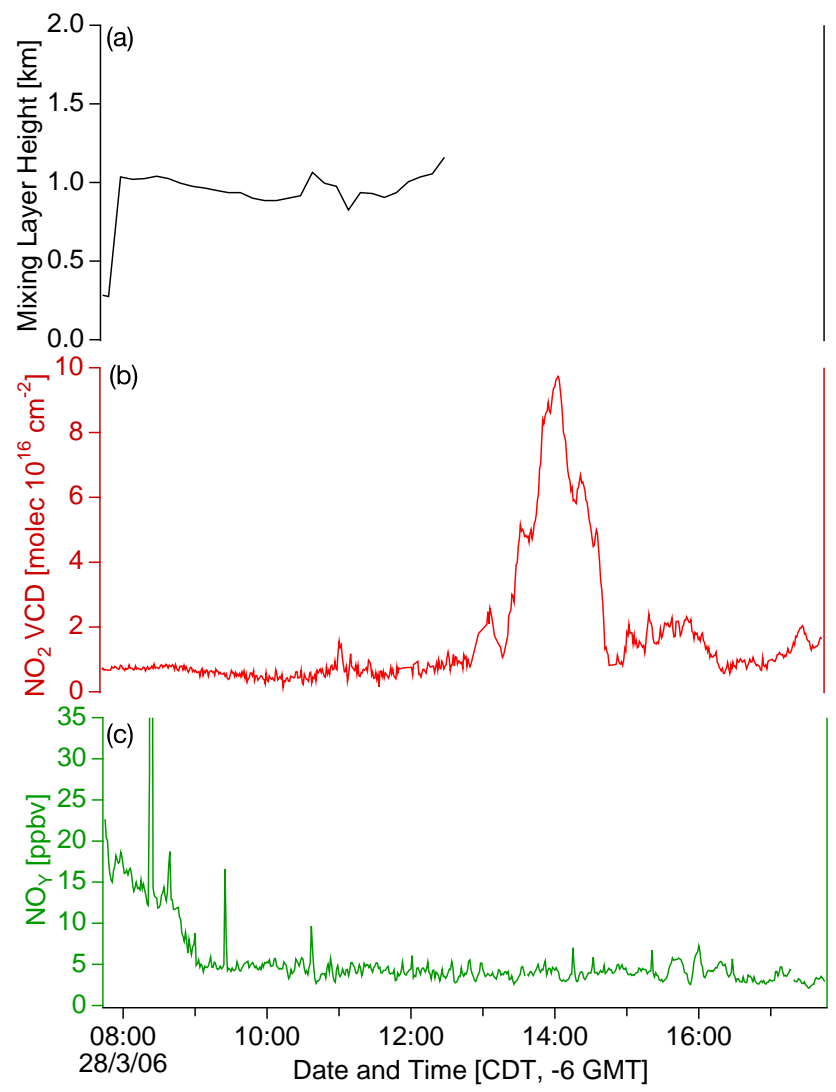

Fig. 12. Measurements of (a) ceilometer mixing layer height (b) tropospheric $\mathrm{NO}_{2}$ vertical column densities and (c) surface $\mathrm{NO}_{2}$ mixing ratios on 28 March 2006.

Figure 13 shows the DOAS $\mathrm{O}_{4}$ AMF for 28 March 2006. A large enhancement in the $\mathrm{O}_{4} \mathrm{AMF}$ and hence the optical photon path length was detected starting at 12:50 CDT and continuing until 14:50 CDT. In addition to an increased $\mathrm{O}_{4}$ AMF, the intensity of the photons reaching the spectrometer decreases, indicating that the large enhancement in the optical path length is due to multiple scattering within thick clouds passing over the Tenango del Aire research site. The ceilometer data supports this conclusion detecting a cloud present above the Tenango del Aire research site from about 13:00 to 14:00 CDT and another cloud from 14:00 to 15:00 CDT. The cloud height between 13:00 and 14:00 CDT was $\sim 200 \mathrm{~m}$ above ground a.g.l. and the height of the precipitating cloud between 14:00 and 15:00 CDT was $\sim 500 \mathrm{~m}$ a.g.l. The algorithm for the retrieval of the the MLH fails during periods of rainfall. Therefore, the MLH curve in Fig. 12 is not indicated past 12:30 CDT due to the presence of rain droplets.

The increase in the $\mathrm{O}_{4}$ AMF during the first cloud was from 1.0 to 4.5 air masses. This increase in the $\mathrm{O}_{4} \mathrm{AMF}$ due to multiple scattering within the cloud accounts for the majority of the increase in the tropospheric $\mathrm{NO}_{2} \mathrm{VCD}$, but 


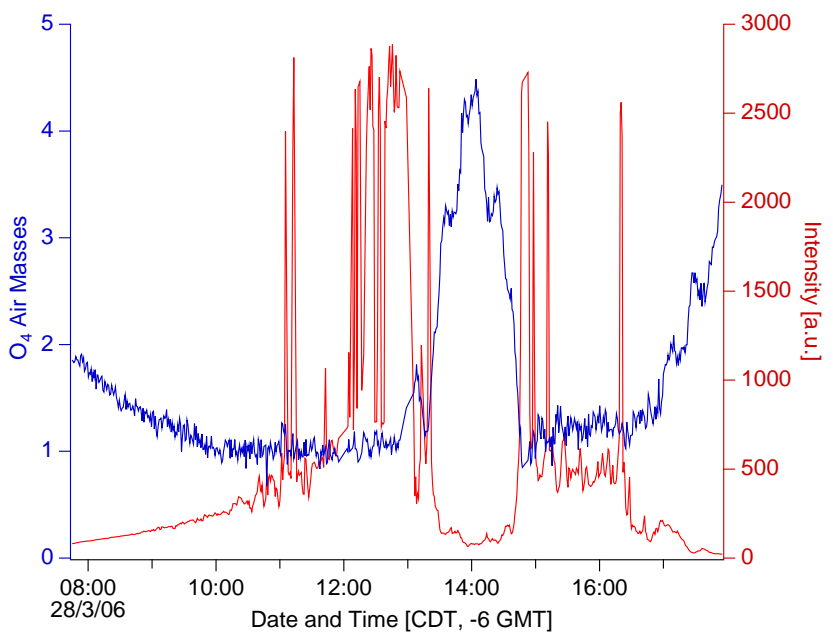

Fig. 13. The $\mathrm{O}_{4}$ AMF (blue line) and intensity (red line) of photons reaching the spectrometer in the wavelength region of the $\mathrm{O}_{4}$ retrievals on 28 March 2006.

not all of it. A portion of the tropospheric $\mathrm{NO}_{2} \mathrm{VCD}$ enhancement is therefore due to an actual increase in the column density of $\mathrm{NO}_{2}$ within the cloud. This increase is likely due to $\mathrm{NO}_{2}$ produced from lightning or a transport of $\mathrm{NO}_{2}$ into the convective cloud from its surroundings, (Pickering et al., 1992; Solomon et al., 1999; Langford et al., 2004; Erle et al., 1995; Pfleilsticker et al., 1999, and references therein). Figure 14 shows lightning was detected in the vicinity of the Tenango del Aire research site on the afternoon of 28 March by the World Wide Lightning Location Network (WWLLN), suggesting that the $\mathrm{NO}_{2}$ within the cloud is likely due to lightning (www.wwlln.net). However, doing an analysis to estimate the amount of $\mathrm{NO}_{2}$ produced by lightning as done by Langford et al. (2004) or Fraser et al. (2007) is not possible due to the low resolution, $\sim 20 \mathrm{~km}$, of the WWLLN in Mexico and the lack of radar measurements.

\section{Conclusions}

Surface and remote sensing instruments at the Tenango del Aire research site during the MILAGRO 2006 campaign are used to analyze air pollution transport events to the southeast of Mexico City. Using surface $\mathrm{NO}, \mathrm{NO}_{\mathrm{x}}$ and $\mathrm{NO}_{\mathrm{y}}$ mixing ratios, tropospheric $\mathrm{NO}_{2} \mathrm{VCD}$ and meteorological data, the data set was divided into three air pollution transport case studies. Case 1 days are characterized by northerly winds for the majority of the day, which transports several plumes from the north through the Tenango del Aire research site that are detected by both DOAS and surface $\mathrm{NO}_{2}$ measurements. Case 2 days are characterized by southerly winds for the entire day. The air to the south is relatively clean and no major enhancements in the DOAS nor the surface $\mathrm{NO}_{2}$ measurements are observed. Case 3 days appear to be very simi-

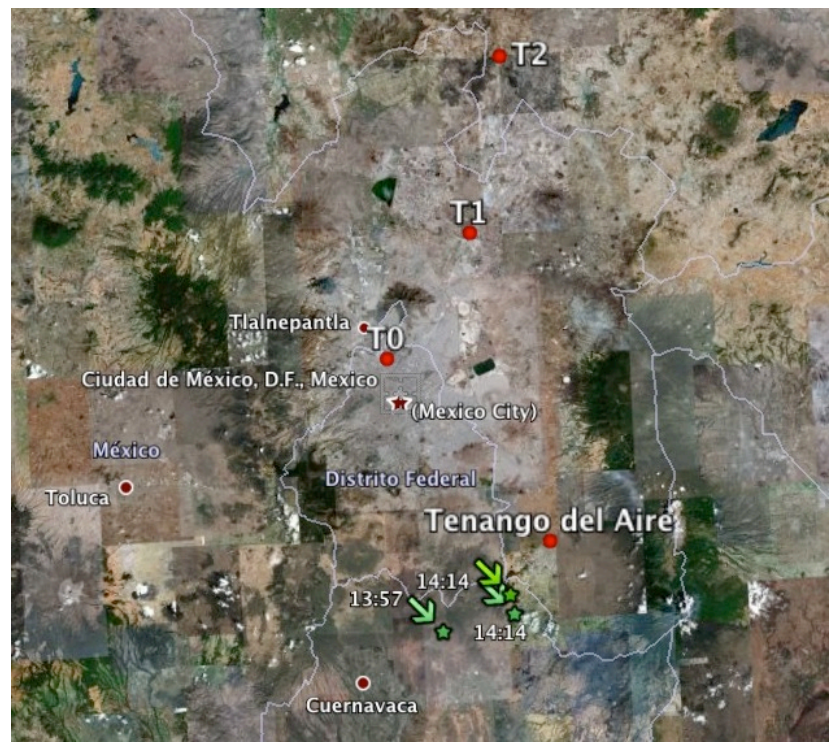

Fig. 14. The green arrows show the time and location of lightning strikes detected by the World Wide Lightning Network (WWWLLN) near the Tenango del Aire research site on 28 March 2006 (www.wwlln.net).

lar to Case 2 days in that the dominant wind direction was southerly and no major enhancements in the surface $\mathrm{NO}_{\mathrm{y}}$ measurements were observed. However, during the afternoon on Case 3 days, the DOAS $\mathrm{NO}_{2}$ measurements detect large $\mathrm{NO}_{2}$ enhancements that are not observed in the surface $\mathrm{NO}, \mathrm{NO}_{\mathrm{x}}$ and $\mathrm{NO}_{\mathrm{y}}$ measurements.

The combination of surface monitors and DOAS column density measurements, in conjunction with ceilometer and meteorological data, give the possibility to differentiate between localized and aged plumes, providing important information about the extent of mixing in the pollution layer and detected $\mathrm{NO}_{2}$ enhancements above the MLH. The analysis of a Case 1 day, 13 March 2006, highlights the difference between DOAS column measurements and surface mixing ratio measurements. DOAS column density measurements observe the total number of molecules in the atmosphere while in-situ instruments near the surface provide local mixing ratios. Therefore, as shown in the analysis of 13 March 2006, the $\mathrm{NO}_{2}$ mixing ratio within a variety of plumes can remain constant even though the remotely measured $\mathrm{NO}_{2}$ column density may change.

The unique data set is also used to determine the vertical homogeneity of the ML. If the MLH is well known, the tropospheric $\mathrm{NO}_{2}$ VCD measurements can also be used to estimate a surface mixing ratio. The measured surface mixing ratio should be equal to the estimated DOAS mixing ratio if $\mathrm{NO}_{2}$ is well mixed within the $\mathrm{ML}$ and the $\mathrm{NO}_{2}$ molecules observed by the DOAS instrument reside within the ML. This concept was tested using the tropospheric DOAS $\mathrm{NO}_{2} \mathrm{VCD}$ 
measurements on 13 March 2006. The analysis shows that during two of the plumes transported through the Tengango del Aire research site, $\mathrm{NO}_{2}$ was well mixed within the ML.

In addition, the analysis of Case 3 days demonstrates the ability of DOAS measurements to determine the influence of pollution sources in the Mexico City basin that may reside above the ML. On 28 March 2006, a large enhancement in the tropopsheric $\mathrm{NO}_{2} \mathrm{VCD}$ is observed with no coinciding surface $\mathrm{NO}_{\mathrm{y}}$ enhancement. We show the observed $\mathrm{NO}_{2}$ enhancement in the DOAS measurement is likely do to lightning produced $\mathrm{NO}$, which is rapidly oxidized to $\mathrm{NO}_{2}$. This exhibits the ability of DOAS measurements to provide important information regarding the influence of natural and anthropogenic pollution sources that may reside above the ML, such as $\mathrm{NO}_{2}$ produced from lightning and biomass burning, as well as $\mathrm{SO}_{2}$ emissions from volcanic activity, on pollution events within the Mexico City metropolitan area.

Acknowledgements. This material is based upon work supported by the National Science Foundation International Research Fellowship Program under Grant No. 0653087, the SEMARNAT-CONACYT Grant No. C01-0116 and the MCMA 2006 project.

The authors acknowledge R. T. Jardón and A. Torres for the operation of the mobile laboratory at the Tenango del Aire research site.

Edited by: S. Madronich

\section{References}

de Foy, B., Varela, J. R., Molina, L. T., and Molina, M. J.: Rapid ventilation of the Mexico City basin and regional fate of the urban plume, Atmos. Chem. Phys., 6, 2321-2335, 2006,

http://www.atmos-chem-phys.net/6/2321/2006/.

de Foy, B., Fast, J. D., Paech, S. J., Phillips, D., Walters, J. T., Coulter, R. L., Martin, T. J., Pekour, M. S., Shaw, W. J., Kastendeuch, P. P., Marley, N. A., Retama, A., and Molina, L. T.: Basinscale wind transport during the MILAGRO field campaign and comparison to climatology using cluster analysis, Atmos. Chem. Phys., 8, 1209-1224, 2008,

http://www.atmos-chem-phys.net/8/1209/2008/.

DeCarlo, P. F., Dunlea, E. J., Kimmel, J. R., Aiken, A. C., Sueper, D., Crounse, J., Wennberg, P. O., Emmons, L., Shinozuka, Y., Clarke, A., Zhou, J., Tomlinson, J., Collins, D. R., Knapp, D., Weinheimer, A. J., Montzka, D. D., Campos, T., and Jimenez, J. L.: Fast airborne aerosol size and chemistry measurements above Mexico City and Central Mexico during the MILAGRO campaign, Atmos. Chem. Phys., 8, 4027-4048, 2008, http://www.atmos-chem-phys.net/8/4027/2008/.

Doran, J. C., Barnard, J. C., Arnott, W. P., Cary, R., Coulter, R., Fast, J. D., Kassianov, E. I., Kleinman, L., Laulainen, N. S., Martin, T., Paredes-Miranda, G., Pekour, M. S., Shaw, W. J., Smith, D. F., Springston, S. R., and Yu, X.-Y.: The T1-T2 study: evolution of aerosol properties downwind of Mexico City, Atmos. Chem. Phys., 7, 1585-1598, 2007, http://www.atmos-chem-phys.net/7/1585/2007/.
Emeis, S., Jahn, C., Münkel, C., Muensterer, C., and Schäfer, K.: Multiple atmospheric layering and mixing-layer height in the Inn valley observed by remote sensing, Meteorol. Z., 16, 415-424, 2007.

Erle, F., Pfeilsticker, K., and Platt, U.: On the influence of tropospheric clouds on zenith-scattered-light measurements of stratospheric species, Geophys. Res. Lett., 22, 2725-2728, 1995.

Fraser, A., Goutail, F., McLinden, C. A., Melo, S. M. L., and Strong, K.: Lightning-produced $\mathrm{NO}_{2}$ observed by two ground-based UV-visible spectrometers at Vanscoy, Saskatchewan in August 2004, Atmos. Chem. Phys., 7, 1683-1692, 2007, http://www.atmos-chem-phys.net/7/1683/2007/.

Friess, U., Monks, P., Remedios, J., Rozanov, A., Sinreich, R., Wagner, T., and Platt, U.: MAX-DOAS $\mathrm{O}_{4}$ measurements: A new technique to derive information on atmospheric aerosols: 2. Modeling studies, J. Geophys. Res.-Atmos., 111, D14, doi:10.1029/2005JD006618, 2006.

Gil, M., Yela, M., Gunn, L. N., Richter, A., Alonso, I., Chipperfield, M. P., Cuevas, E., Iglesias, J., Navarro, M., Puentedura, O., and Rodríguez, S.: $\mathrm{NO}_{2}$ climatology in the northern subtropical region: diurnal, seasonal and interannual variability, Atmos. Chem. Phys., 8, 1635-1648, 2008, http://www.atmos-chem-phys.net/8/1635/2008/.

Grainger, J. and Ring, J.: Anomalous Fraunhofer Line Profiles, Nature, 193, 762 pp., 1962.

Greenblatt, G. D., Orlando, J. J., Burkholder, J. B., and Ravishankara, A. R.: Absorption Measurements of Oxygen between $330 \mathrm{~nm}$ and $1140 \mathrm{~nm}$, J. Geophys. Res.-Atmos., 95, 1857718582, 1990.

Heckel, A., Richter, A., Tarsu, T., Wittrock, F., Hak, C., Pundt, I., Junkermann, W., and Burrows, J. P.: MAX-DOAS measurements of formaldehyde in the Po-Valley, Atmos. Chem. Phys., 5, 909918, 2005

Hennigan, C. J., Sullivan, A. P., Fountoukis, C. I., Nenes, A., Hecobian, A., Vargas, O., Peltier, R. E., Case Hanks, A. T., Huey, L. G., Lefer, B. L., Russell, A. G., and Weber, R. J.: On the volatility and production mechanisms of newly formed nitrate and water soluble organic aerosol in Mexico City, Atmos. Chem. Phys., 8, 3761-3768, 2008, http://www.atmos-chem-phys.net/8/3761/2008/.

Kurucz, R., Furenhild, I., Brault, J., and Testermann, L.: Solar Flux from $296 \mathrm{~nm}$ to $1300 \mathrm{~nm}$, National Solar Observation Atlas, Harvard Univertisty, Cambridge, Massachusetts, 1984.

Ladstätter-Weißenmayer, A., Altmeyer, H., Bruns, M., Richter, A., Rozanov, A., Rozanov, V., Wittrock, F., and Burrows, J. P.: Measurements of $\mathrm{O}_{3}, \mathrm{NO}_{2}$ and $\mathrm{BrO}$ during the INDOEX campaign using ground based DOAS and GOME satellite data, Atmos. Chem. Phys., 7, 283-291, 2007,

http://www.atmos-chem-phys.net/7/283/2007/.

Langford, A. O., Portmann, R. W., Daniel, J. S., Miller, H. L., and Solomon, S.: Spectroscopic measurements of $\mathrm{NO}_{2}$ in a Colorado thunderstorm: Determination of the mean production by cloudto-ground lightning flashes, J. Geophys. Res.-Atmos., 109, D11, doi:10.1029/2003JD004158, 2004.

Levenberg, K.: A Method for the Solution of Certain Problems in Least Squares, Q. Appl. Math., 2, 164-168, 1944.

Marquardt, D.: An Algorithm for Least-Squares Estimation of Nonlinear Parameters, SIAM J. Appl. Math., 11, 431-441, 1963.

McClenny, W.: Recommended Methods for Ambient Air Monitor- 
ing of $\mathrm{NO}, \mathrm{NO}_{2}, \mathrm{NO}_{\mathrm{y}}$ and individual $\mathrm{NO}_{\mathrm{z}}$ species, Tech. rep., US Environmental Protection Agency, Traingle Park, NC 27711, 2000.

Melamed, M. L., Langford, A. O., Daniel, J. S., Portmann, R. W., Miller, H. L., Eubank, C. S., Schofield, R., Holloway, J., and Solomon, S.: Sulfur dioxide emission flux measurements from point sources using airborne near ultraviolet spectroscopy during the New England Air Quality Study 2004, J. Geophys. Res.Atmos., 113, D02305, doi:10.1029/2007jd008923, 2008.

Moffet, R. C., de Foy, B., Molina, L. T., Molina, M. J., and Prather, K. A.: Measurement of ambient aerosols in northern Mexico City by single particle mass spectrometry, Atmos. Chem. Phys., 8, 4499-4516, 2008, http://www.atmos-chem-phys.net/8/4499/2008/.

Molina, L. T. and Molina, M. J. (Eds.): Air Quality in the Mexico Megacity: An Integrated Assesment, vol. 2 of Alliance for Global Sustainability Bookseries, Kluwer Academic Publishers, Dordrecht, 1-384, 2002.

Molina, L. T., Kolb, C. E., de Foy, B., Lamb, B. K., Brune, W. H., Jimenez, J. L., Ramos-Villegas, R., Sarmiento, J., ParamoFigueroa, V. H., Cardenas, B., Gutierrez-Avedoy, V., and Molina, M. J.: Air quality in North America's most populous city overview of the MCMA-2003 campaign, Atmos. Chem. Phys., 7, 2447-2473, 2007,

http://www.atmos-chem-phys.net/7/2447/2007/.

Münkel, C., Emeis, S., Müller, W., and Schäfrer, K.: Aerosol concentration measurements with a lidar ceilometer: Results of a one year measuring campaign, Proc. SPIE, 5235, 486 pp., doi:10.1117/12.511104, 2004.

Noxon, J.: Nitrogen Dioxide in Stratosphere and Troposphere Measured by Ground-Based Absorption Spectroscopy, Science, 189, 547-549, 1975

Perliski, L. and Solomon, S.: On the Evaluation of Air Mass Factors for Atmospheric Near-Ultraviolet and Visible Absorption Spectroscopy, J. Geophys. Res.-Atmos., 96, 10363-10374, 1993.

Perner, D. and Platt, U.: Detection of Nitrous-Acid in the Atmosphere by Differential Optical-Absorption, Geophys. Res. Lett., 6, 917-920, 1979.

Pfeilsticker, K., Bosch, H., Camy-Peyret, C., Fitzenberger, R., Harder, H., and Osterkamp, H.: First atmospheric profile measurements of UV/visible $\mathrm{O}_{4}$ absorption band intensities: Implications for the spectroscopy, and the formation enthalpy of the $\mathrm{O}_{2}-\mathrm{O}_{2}$ dimer, Geophys. Res. Lett., 28, 4595-4598, 2001.

Pfleilsticker, K., Arlander, D., Burrows, J., Erle, F., Gil, M., Goutail, F., Hermans, C., Lambert, J., Platt, U., Pommereau, J., Ritcher, A., Sarkissian, A., Van Roozendael, M., Wagner, T., and Winterrath, T.: Intercomparison of the influence of tropospheric clouds on UV-Visible absorptions detected during the NDSC Intercomparison Campaign at OHP in June 1996, Geophys. Res. Lett., 8, 1169-1172, 1999.

Pickering, K., Thompson, A., Scala, J., Tao, W., Dickerson, R., and Simpson, J.: Free Tropospheric Ozone Production Following Entrainment of Urban Plumes Into Deep Convection, J. Geophys. Res.-Atmos., 97, 17985-18000, 1992.

Platt, U. and Stutz, J.: Differential Optical Absorption Spectroscopy; Principles and Application, Springer-Verlag $\mathrm{GmbH}$, Heidelberg, Germany, 2008.

Platt, U., Marquard, L., Wagner, T., and Perner, D.: Corrections for zenith scattered light DOAS, Geophys. Res. Lett., 24, 1759-
1762, 1997.

Querol, X., Pey, J., Minguillón, M. C., Pérez, N., Alastuey, A., Viana, M., Moreno, T., Bernabé, R. M., Blanco, S., Cárdenas, B., Vega, E., Sosa, G., Escalona, S., Ruiz, H., and Artíñano, B.: PM speciation and sources in Mexico during the MILAGRO-2006 Campaign, Atmos. Chem. Phys., 8, 111-128, 2008, http://www.atmos-chem-phys.net/8/111/2008/.

Raga, G. B., Kok, G. L., Baumgardner, D., Baez, A., and Rosas, I.: Evidence for volcanic influence on Mexico City aerosols, Geophys. Res. Lett., 26, 1149-1152, 1999.

Sanders, R. W.: Improved analysis of atmospheric absorption spectra by including the temperature dependence of $\mathrm{NO}_{2}$, J. Geophys. Res.-Atmos., 101, 20945-20952, 1996.

Schäfer, K., Emeis, S., Rauch, C., Münkel, C., and Voigt, S.: Determination of mixing-layer heights from ceilometer data, Proc. SPIE, 5571, 248 pp., doi:10.1117/12.565592, 2004.

Sinreich, R., Friess, U., Wagner, T., and Platt, U.: Multi axis differential optical absorption spectroscopy (MAX-DOAS) of gas and aerosol distributions, Faraday Discuss., 130, 153-164, 2005.

Solomon, S., Schmeltekopf, A. L., and Sanders, R. W.: On the Interpretation of Zenith Sky Absorption-Measurements, J. Geophys. Res.-Atmos., 92, 8311-8319, 1987.

Solomon, S., Portmann, R. W., Sanders, R. W., Daniel, J. S., Madsen, W., Bartram, B., and Dutton, E. G.: On the role of nitrogen dioxide in the absorption of solar radiation, J. Geophys. Res.Atmos., 104, 12047-12058, 1999.

Stone, E. A., Snyder, D. C., Sheesley, R. J., Sullivan, A. P., Weber, R. J., and Schauer, J. J.: Source apportionment of fine organic aerosol in Mexico City during the MILAGRO experiment 2006, Atmos. Chem. Phys., 8, 1249-1259, 2008, http://www.atmos-chem-phys.net/8/1249/2008/.

Thornhill, D. A., de Foy, B., Herndon, S. C., Onasch, T. B., Wood, E. C., Zavala, M., Molina, L. T., Gaffney, J. S., Marley, N. A., and Marr, L. C.: Spatial and temporal variability of particulate polycyclic aromatic hydrocarbons in Mexico City, Atmos. Chem. Phys., 8, 3093-3105, 2008, http://www.atmos-chem-phys.net/8/3093/2008/.

Velasco, E., Márquez, C., Bueno, E., Bernabé, R. M., Sánchez, A., Fentanes, O., W“hrnschimmel, H., Cárdenas, B., Kamilla, A., Wakamatsu, S., and Molina, L. T.: Vertical distribution of ozone and VOCs in the low boundary layer of Mexico City, Atmos. Chem. Phys., 8, 3061-3079, 2008, http://www.atmos-chem-phys.net/8/3061/2008/.

Voigt, S., Orphal, J., Bogumil, K., and Burrows, J. P.: The temperature dependence (203-293 K) of the absorption cross sections of $\mathrm{O}_{3}$ in the $230-850 \mathrm{~nm}$ region measured by Fourier-transform spectroscopy, J. Photoch. Photobio. A, 143, 1-9, 2001.

Voigt, S., Orphal, J., and Burrows, J. P.: The temperature and pressure dependence of the absorption cross-sections of $\mathrm{NO}_{2}$ in the $250-800 \mathrm{~nm}$ region measured by Fourier-transform spectroscopy, J. Photoch. Photobio. A, 149, 1-7, 2002.

Wagner, T., Erle, F., Marquard, L., Otten, C., Pfeilsticker, K., Senne, T., Stutz, J., and Platt, U.: Cloudy sky optical paths as derived from differential optical absorption spectroscopy observations, J. Geophys. Res.-Atmos., 103, 25307-25321, 1998.

Wagner, T., von Friedeburg, C., Wenig, M., Otten, C., and Platt, U.: UV-visible observations of atmospheric $\mathrm{O}_{4}$ absorptions using direct moonlight and zenith-scattered sunlight for clear-sky and cloudy sky conditions, J. Geophys. Res.-Atmos., 107, D20, 
doi:10.1029/2001JD001026, 2002.

Wagner, T., Dix, B., von Friedeburg, C., Friess, U., Sanghavi, S., Sinreich, R., and Platt, U.: MAX-DOAS $\mathrm{O}_{4}$ measurements: A new technique to derive information on atmospheric aerosols - Principles and information content, J. Geophys. Res.-Atmos., 109, D22205, doi:10.1029/2004JD004904, 2004.

Wang, P., Richter, A., Bruns, M., Rozanov, V. V., Burrows, J. P., Heue, K.-P., Wagner, T., Pundt, I., and Platt, U.: Measurements of tropospheric $\mathrm{NO}_{2}$ with an airborne multi-axis DOAS instrument, Atmos. Chem. Phys., 5, 337-343, 2005, http://www.atmos-chem-phys.net/5/337/2005/.

Wang, P., Richter, A., Bruns, M., Burrows, J. P., Scheele, R., Junkermann, W., Heue, K.-P., Wagner, T., Platt, U., and Pundt, I.: Airborne multi-axis DOAS measurements of tropospheric $\mathrm{SO}_{2}$ plumes in the Po-valley, Italy, Atmos. Chem. Phys., 6, 329-338, 2006, http://www.atmos-chem-phys.net/6/329/2006/.
Whiteman, C., Zhong, S., Bian, X., Fast, J., and Doran, J.: Boundary layer evolution and regional-scale diurnal circulations over the Mexico Basin and Mexican plateau, J. Geophys. Res.Atmos., 105, 10081-10102, 2000.

Wittrock, F., Oetjen, H., Richter, A., Fietkau, S., Medeke, T., Rozanov, A., and Burrows, J. P.: MAX-DOAS measurements of atmospheric trace gases in Ny-Ålesund - Radiative transfer studies and their application, Atmos. Chem. Phys., 4, 955-966, 2004, http://www.atmos-chem-phys.net/4/955/2004/.

Yokelson, R. J., Urbanski, S. P., Atlas, E. L., Toohey, D. W., Alvarado, E. C., Crounse, J. D., Wennberg, P. O., Fisher, M. E., Wold, C. E., Campos, T. L., Adachi, K., Buseck, P. R., and Hao, W. M.: Emissions from forest fires near Mexico City, Atmos. Chem. Phys., 7, 5569-5584, 2007, http://www.atmos-chem-phys.net/7/5569/2007/. 